\title{
THE DETECTION OF METHICILLIN RESISTANCE IN STAPHYLOCOCCUS AUREUS
}

\author{
J. H. Hewitt, A. W. Coe and M. T. Parker \\ Cross-Infection Reference Laboratory, Colindale, London
}

Since the first report from this laboratory of the isolation from patients of Staphylococcus aureus cultures resistant to methicillin (Jevons, 1961), we have carried out a continuous survey of resistance to this antibiotic in cultures sent to us for phage-typing (Jevons, Coe and Parker, 1963; Parker and Jevons, 1964; Dyke, Jevons and Parker, 1966). We used a screening test in which a paper disk impregnated with methicillin was placed on the phage-typing plate. Confirmation of resistance was obtained by repeating the disk test and then measuring the minimum inhibitory concentration (MIC) of methicillin for the cultures in a tube dilution test. Unless the culture showed resistance in all three tests it was considered to be sensitive. It became apparent, however, that these criteria for resistance were somewhat too strict and led to the exclusion of some resistant strains.

The difficulties in testing for methicillin resistance in $S$. aureus arise from the "heterogeneous " nature of the resistance (Chabbert and Baudens, 1962). When grown in ordinary nutrient media at $37^{\circ} \mathrm{C}$, the individual cocci in a resistant culture show wide quantitative differences in resistance to the antibiotic; most of them have a normal or only slightly increased resistance, and only a small minority appear to be highly resistant (Knox, 1961). Although the highly resistant cells usually have a normal growth-rate in the absence of methicillin (Dyke, 1969), they grow relatively slowly in its presence (Rolinson, 1961). Heavy inocula must be used in sensitivity tests, and even then the results are often not clear-cut. In disk diffusion tests, some resistant strains grow continuously up to the disk, but others show only a slight reduction in zone size and the presence of a few small colonies of resistant organisms within the zone of inhibition (Parker and Jevons). When the tube dilution test is read after overnight incubation at $37^{\circ} \mathrm{C}$, the $\mathrm{MIC}$ of methicillin for a series of staphylococci forms a continuous series from the obviously sensitive to the obviously resistant (Dyke et al.), and with some of the "borderline" cultures there may be as much as a fourfold difference in the end-point on repeated testing.

Sutherland and Rolinson (1964) suggested that tube-dilution sensitivity tests with methicillin should be incubated for $48 \mathrm{hr}$ to permit the resistant minority population to multiply sufficiently to cause turbidity. Barber (1964) showed that most of the relatively sensitive, majority population in resistant cultures grew and formed colonies of normal size in the presence of $10 \mu \mathrm{g}$ methicillin per $\mathrm{ml}$ on solid medium with 5 per cent. added salt, and Annear (1968) reported that methicillin-resistant cultures showed enhanced resistance when grown in ordinary nutrient media at $31^{\circ} \mathrm{C}$, but that the temperature of incubation had little effect on the susceptibility to antibiotic of sensitive cultures.

We now describe attempts to find a more accurate test for use in our survey and to evaluate routine methods for the detection of resistance in hospital laboratories.

Received 6 Feb. 1969; accepted 8 Apr. 1969.

J. MED. MICROBIOL.-VOL. 2 (1969) 


\section{MATERIALS AND METHODS}

\section{Cultures}

Since October 1960, some 85,000 cultures of Staphylococcus aureus sent to the CrossInfection Reference Laboratory for phage-typing have been examined for sensitivity to methicillin by the disk diffusion screening test, and at various times other tests were applied to selections of the cultures, as will be described. A smaller sample of 2122 cultures isolated consecutively from in-patients in eight London hospitals in the years 1964-67 was also examined, but in this case two different screening tests were used, the disk test and a spot test on methicillin-salt agar.

The Oxford staphylococcus (NCTC6571) was used as an antibiotic-sensitive control culture.

\section{Antibiotics}

Methicillin (Celbenin) and cloxacillin (Orbenin) were supplied by Beecham Research Laboratories. Primary dilutions of weighed amounts were made in distilled water and stored in small aliquots for up to 4 days at $-5^{\circ} \mathrm{C}$. Fresh working dilutions were made for each experiment.

\section{Media}

Nutrient broth. Oxoid nutrient broth no. 2 was used.

Nutrient agar. Unless stated otherwise, nutrient agar was Oxoid nutrient broth no. 2 solidified with 1.1 per cent. powdered New Zealand agar (Davis).

Blood agar. A layer of nutrient agar containing 5 per cent. horse blood was poured over a layer of peptone agar ( 1 per cent. Evans peptone, 0.5 per cent. $\mathrm{NaCl}, 1.1$ per cent. powdered New Zealand agar).

Salt agar. This was nutrient agar with the addition of 5 per cent. $(\mathrm{w} / \mathrm{v}) \mathrm{NaCl}$.

Phage-typing agar. This consisted of a bottom layer of peptone agar (1 per cent. Evans peptone, 0.5 per cent. $\mathrm{NaCl}, 1.2$ per cent. agar) covered by a layer of nutrient agar ( 2 per cent. Difco nutrient broth, $1 \cdot 2$ per cent. agar). Japanese shred agar was used in both layers, and $400 \mu \mathrm{g} \mathrm{CaCl}_{2}$ was added per $\mathrm{ml}$ to the top layer when test-plates showed that this was necessary for optimal phage lysis (Blair and Williams, 1961).

Solid media containing antibiotics. Appropriate dilutions of methicillin and cloxacillin, not exceeding 2 per cent. of the final volume, were added to melted nutrient agar or salt agar at a temperature of $45^{\circ}-50^{\circ} \mathrm{C}$ and poured into plates immediately.

\section{Antibiotic-resistance tests}

Minimum inhibitory concentration of antibiotic in broth. The MIC was measured in a tube-dilution test. Doubling dilutions of antibiotic were made in 1-ml volumes of broth. Each tube was inoculated by means of a calibrated pipette with one $0.02-\mathrm{ml}$ drop of a turbid 4-6-hr broth culture of staphylococci, giving an inoculum of $c .10^{6}$ viable organisms. After incubation, the tubes were examined for turbidity without previous shaking. The Oxford staphylococcus was included as control in each batch of tests.

Disk diffusion test. Disks of Ford blotting paper, $6 \mathrm{~mm}$ in diameter, were sterilised by autoclaving, and one $0.02-\mathrm{ml}$ drop of an appropriate dilution of antibiotic was placed on each with a calibrated pipette. The disks were immediately dried under vacuum at a reduced temperature and stored over $\mathrm{CaCl}_{2}$ at $4^{\circ} \mathrm{C}$. Fresh batches were prepared monthly. Plates of media were spread or flocded with undiluted turbid broth cultures of staphylococci and allowed to dry at room temperature. The disks were then applied and the plates were incubated overnight. The width of the zones of inhibition was recorded as the diameter of the zone minus the diameter of the disk.

Growth on solid medium containing antibiotic. With exceptions that will be mentioned, tests were carried out on salt agar. Inocula of staphylococci were applied to the surface of the medium by means of a mechanical applicator as drops of undiluted broth culture (c. $0.002 \mathrm{ml}$ ) containing about $10^{5}$ organisms. Control plates without antibiotic were included in each test, and the Oxford staphylococcus was inoculated on every plate. 


\section{RESULTS \\ Preliminary observations}

From 1960 to 1966, resistance to methicillin was detected and confirmed as follows. Disks containing $10 \mu \mathrm{g}$ methicillin were placed on a peripheral area of the phage-typing plate after it had been flooded with a 4-6-hr broth culture of Staphylococcus aureus and had been dried for $30 \mathrm{~min}$. with the lid removed. Plates were incubated overnight at $30^{\circ} \mathrm{C}$. Cultures that showed growth up to the disk or obvious narrowing of the zone of inhibition were recorded provisionally as resistant and examined further. First, the disk test was repeated on a blood agar plate. The inoculum, taken from an agar slope, was spread heavily on a quarter-plate and then streaked out. One methicillin disk was placed on the area of the primary inoculum and two other disks on less heavily inoculated areas. The plate was incubated overnight at $37^{\circ} \mathrm{C}$. If there was a narrowing of the zone of inhibition or the development of separate colonies within the zone in the heavily inoculated area, the MIC of methicillin was determined in broth with an inoculum derived from a single colony of the plated culture. Organisms were finally considered resistant only if they gave evidence of resistance in both of the disk tests and if the MIC of methicillin was $12.5 \mu \mathrm{g}$ per $\mathrm{ml}$ or greater after 18 hours' incubation at $37^{\circ} \mathrm{C}$.

We suspected that this method might be a little insensitive because, in hospitals in which a resistant strain was prevalent, cultures were sometimes isolated that had a phage-typing pattern identical with that of the resistant strain, and were resistant in the screening test but appeared to be sensitive in the confirmatory tests. Either the second disk test showed no narrowing of the zone of inhibition or the MIC was $6.25 \mu \mathrm{g}$ per $\mathrm{ml}$ or less. In 1966 , we examined numerous cultures of what was obviously the same strain from one hospital, and although in nearly every case the first disk test suggested resistance, the MIC of one-quarter of the cultures was less than $12.5 \mu \mathrm{g}$ per ml. It seemed, therefore, that these "borderline" cultures included a number that should have been classified as resistant.

\section{Re-examination of the criteria for methicillin resistance}

During 1966 we had tested 11,513 cultures and found 120 of them to be unequivocally resistant. A further 79 cultures appeared to be resistant or probably resistant in the primary disk test, but had subsequently been classified as sensitive. They included 47 that were considered sensitive as a result of the second disk test, and 32 that appeared to be resistant in both disk tests but for which the MIC was less than $12.5 \mu \mathrm{g}$ per $\mathrm{ml}$.

The 79 " borderline" cultures were re-examined as follows: (1) tube dilution tests were carried out at $37^{\circ} \mathrm{C}$ and read after 24 and $42 \mathrm{hr}$; (2) plates of salt agar containing $10 \mu \mathrm{g}$ methicillin per ml were inoculated with drops of culture and incubated at $37^{\circ} \mathrm{C}$ for $18 \mathrm{hr}$; (3) $10-\mu \mathrm{g}$ methicillin disks were placed on segments of nutrient agar plates that had been spread with two $0.02-\mathrm{ml}$ drops of undiluted broth culture, and the plates were incubated at $37^{\circ} \mathrm{C}$ for $18 \mathrm{hr}$. 
The results of the MIC determinations, and their relation to the ability of cultures to grow on salt agar containing methicillin, are summarised in fig. 1 . The MIC values observed after incubation for $24 \mathrm{hr}$ formed a continuous series from $1.56 \mu \mathrm{g}$ per $\mathrm{ml}$ to over $100 \mu \mathrm{g}$ per $\mathrm{ml}$. Although, on the whole, cultures for which the MIC was high were the ones that grew on salt agar in the presence of $10 \mu \mathrm{g}$ methicillin per $\mathrm{ml}$, there was little correspondence between the results of the two tests over the intermediate range of MIC values, $6 \cdot 25-12 \cdot 5 \mu \mathrm{g}$ per ml. When the tube dilution test was read after $42 \mathrm{hr}$, however, the distribution of MICs was bimodal, and all but a small minority of the values were below 12.5 $\mu \mathrm{g}$ per $\mathrm{ml}$ or above $100 \mu \mathrm{g}$ per ml. Moreover, none of the cultures for which the

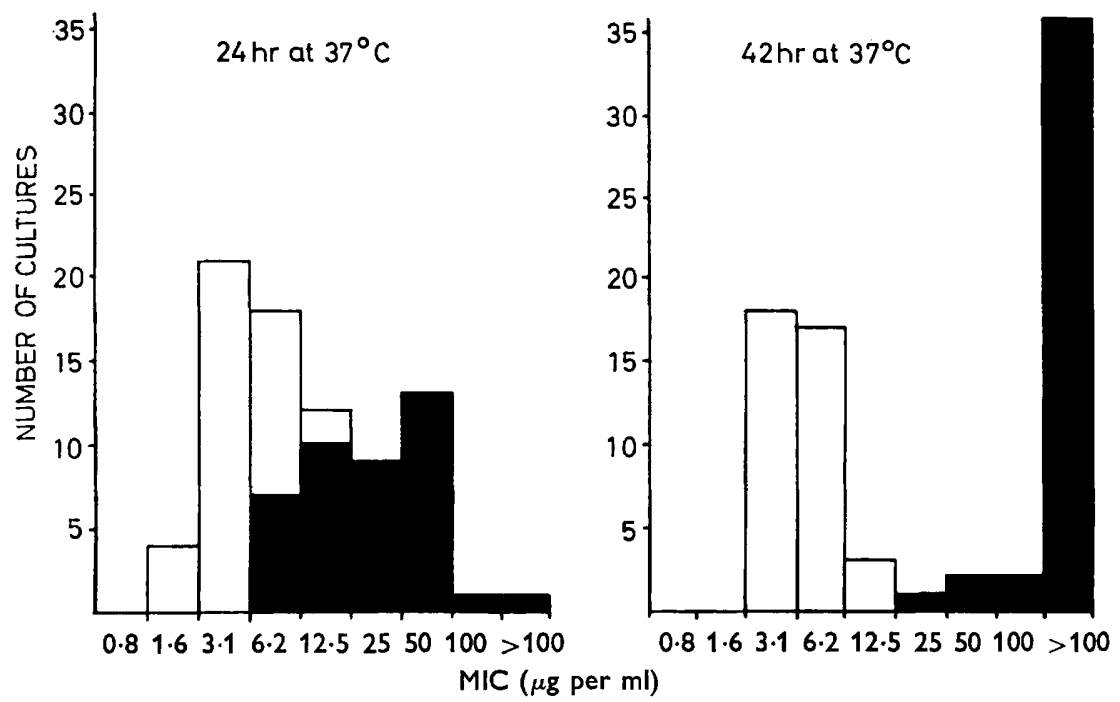

FIG. 1.-Minimum inhibitory concentration (MIC) of methicillin $(\mu \mathrm{g}$ per $\mathrm{ml})$ in tube dilution tests

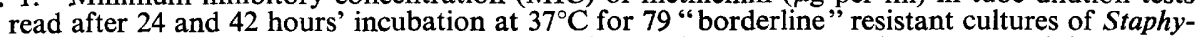
lococcus aureus examined in 1966 . $\quad=$ Cultures that grew on salt agar containing $10 \mu \mathrm{g}$ methicillin per $\mathrm{ml}$.

MIC was $12.5 \mu \mathrm{g}$ per $\mathrm{ml}$ or less gave any growth in $18 \mathrm{hr}$ on salt agar containing $10 \mu \mathrm{g}$ methicillin per ml. Of the 41 cultures for which the MIC was $25 \mu \mathrm{g}$ per ml or greater, 38 gave confluent growth on methicillin salt agar, and the remaining 3 formed numerous discrete colonies.

The " borderline" cultures therefore included 41 that had heterogeneous resistance, in that they multiplied slowly in the presence of $12.5 \mu \mathrm{g}$ methicillin per $\mathrm{ml}$, and generally also in the presence of higher concentrations, and grew on salt agar containing $10 \mu \mathrm{g}$ methicillin per $\mathrm{ml}$. They were clearly distinguishable from the 38 cultures that had neither of these characters.

The behaviour of the two groups of cultures in the disk diffusion test at $37^{\circ} \mathrm{C}$ is shown in fig. 2. All but one of the 41 cultures with heterogeneous resistance had a zone of inhibition of $10 \mathrm{~mm}$ or less; 15 grew right up to the disk, and those that did not showed many small colonies scattered throughout the zone of inhibition. All of the 38 cultures without heterogeneous resistance 
gave zones of $12 \mathrm{~mm}$ diameter or greater; a number of them also showed colonies within the zone, but in many cases these colonies formed a ring near the periphery. It was concluded, therefore, that the disk test at $37^{\circ} \mathrm{C}$ was a moderately good method of detecting methicillin resistance, but that attention had to be paid to small differences in the size and appearance of the zones.

\section{Comparison of the disk diffusion test and the methicillin salt agar test as screening methods}

The use of unduly severe confirmatory tests during 1966 had led to the classification as sensitive of some 25 per cent. of methicillin-resistant cultures

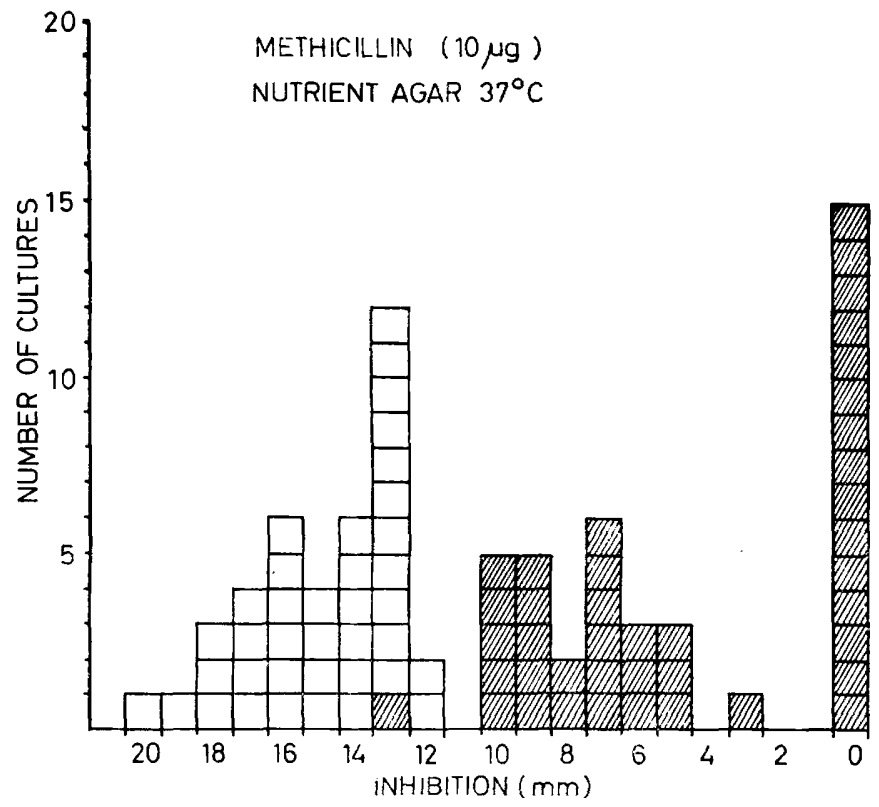

FIG. 2.-Zones of inhibition around 10- $\mu \mathrm{g}$ methicillin disks after overnight incubation at $37^{\circ} \mathrm{C}$ in tests of 79 "borderline" resistant cultures of $S$. aureus examined in 1966. Inhibition (mm) = diameter of zone minus diameter of disk. = Cultures with MIC $\geqq 25 \mu \mathrm{g}$ methicillin per $\mathrm{ml}(42 \mathrm{hr}$ at $37^{\circ} \mathrm{C}$ ).

of S. aureus. Before it was concluded that this was the full extent of our underestimate of the frequency of resistance, the possibility had to be considered that our disk screening test was also insufficiently sensitive. The close correspondence of the results of the tube dilution test read after incubation for $42 \mathrm{hr}$ and the salt agar test led us to investigate the latter as a screening method.

The series of 2122 consecutively isolated cultures from London hospitals had on receipt been phage-typed and tested for methicillin resistance by our routine method. They were examined independently at a later date for their ability to grow on salt agar in $18 \mathrm{hr}$ in the presence of $10 \mu \mathrm{g}$ methicillin per ml. Tube dilution tests were carried out on all cultures that appeared to be resistant 
by either method, and 24 cultures grew in at least $12.5 \mu \mathrm{g}$ methicillin per $\mathrm{ml}$ in $42 \mathrm{hr}$ at $37^{\circ} \mathrm{C}$.

Twenty-two of the 24 methicillin-resistant cultures had been detected by the screening disk test, but 5 of them had later been incorrectly classified as sensitive as a result of the confirmatory tests. An equal number of the resistant cultures grew well on methicillin salt agar, but the two resistant cultures that were missed by this method had been detected by the disk test. When the tests were repeated on a fresh batch of methicillin salt agar both cultures grew well.

The screening disk test therefore detected at least 90 per cent. of the cultures that would grow on methicillin salt agar under optimal conditions, but some batches of the latter medium appeared to give unsatisfactory results.

Variations in the growth of resistant strains on different batches of methicillin salt agar were observed on several subsequent occasions, but growth on the same medium without methicillin was in each case normal. All attempts to produce unsatisfactory batches of medium at will were unsuccessful. Methicillin salt agars made from seven different dehydrated nutrient broth bases were examined in parallel; but no significant differences in performance were observed. In a further series of tests, small variations in the percentage of nutrient base, the salt content, the strength of the agar, the final $p \mathrm{H}$ and the duration of autoclaving had little effect on the selectivity of methicillin salt agar for resistant staphylococci.

As a result of these experiments it was decided to retain the original disk screening test but to use a confirmatory tube dilution test, with a prolonged incubation time at $37^{\circ} \mathrm{C}$. It had occasionally been observed that at $42 \mathrm{hr}$ a resistant culture might show no growth in an intermediate concentration of antibiotic but growth in a higher concentration. Such gaps were very rare after $48 \mathrm{hr}$, and none of the sensitive cultures grew in a higher concentration than $6.25 \mu \mathrm{g}$ methicillin per $\mathrm{ml}$ after $48 \mathrm{hr}$ at $37^{\circ} \mathrm{C}$. From the beginning of 1967, therefore, the confirmatory tube tests were incubated for $48 \mathrm{hr}$, and a MIC of $25 \mu \mathrm{g}$ methicillin per $\mathrm{ml}$ or more was taken as evidence of resistance.

\section{Sensitivity tests at $30^{\circ} \mathrm{C}$}

Annear showed that incubation at temperatures below $37^{\circ} \mathrm{C}$ accentuated the difference between methicillin-sensitive and methicillin-resistant cultures. His work provided an immediate explanation of the success of our disk sensitivity test on the phage-typing plate and our failure to confirm resistance in a proportion of the cultures by the tests used up to 1966 .

We compared the results of disk diffusion tests and tube dilution tests at $37^{\circ} \mathrm{C}$ and $30^{\circ} \mathrm{C}$ on a further series of " borderline " cultures collected between January and June 1968. A total of 7215 cultures had been screened by the disk test at $30^{\circ} \mathrm{C}$ and 260 of them had given presumptive evidence of resistance. In the confirmatory tube dilution test incubated at $37^{\circ} \mathrm{C}$ for $48 \mathrm{hr}$, 201 cultures had given unequivocal evidence of resistance (MIC $\geqq 25 \mu \mathrm{g}$ per $\mathrm{ml}$ ) and 59 had appeared to be sensitive. However, all the cultures had also been examined by the "old" confirmatory tests, and 41 of the 201 resistant cultures would have 


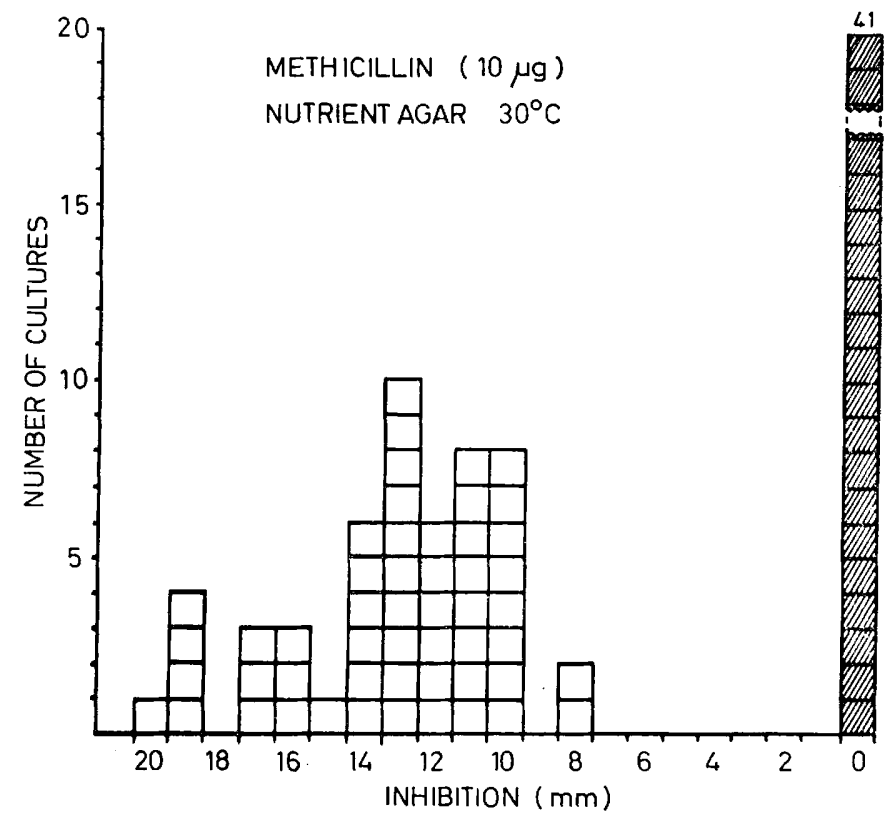

FIG. 3.-Zones of inhibition around $10-\mu \mathrm{g}$ methicillin disks after overnight incubation at $30^{\circ} \mathrm{C}$ in tests of 93 "borderline" resistant cultures of S. aureus examined in 1968. Inhibition (mm) $=$ diameter of zone minus diameter of disk. $=$ Cultures with $\mathrm{MIC} \geqq 25 \mu \mathrm{g}$ methicillin per $\mathrm{ml}$ ( $48 \mathrm{hr}$ at $37^{\circ} \mathrm{C}$ ).

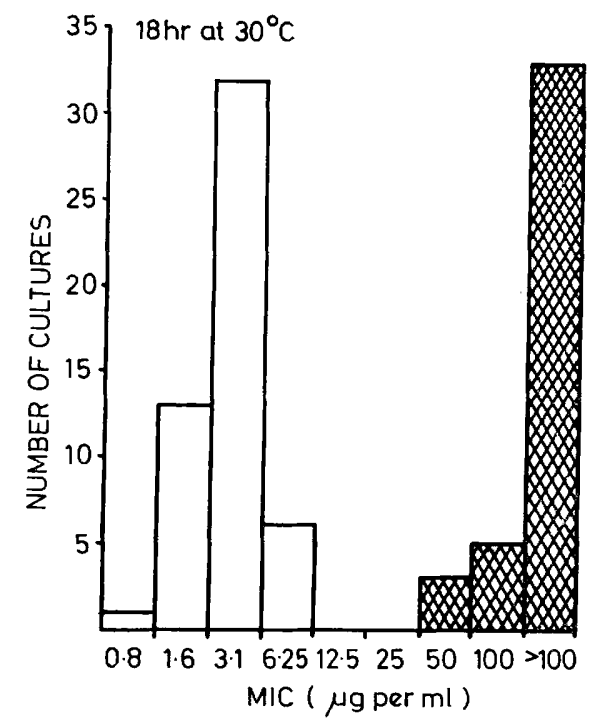

FIG. 4.-Minimum inhibitory concentration of methicillin ( $\mu \mathrm{g}$ per $\mathrm{ml}$ ) in tests read after 18 hours' incubation at $30^{\circ} \mathrm{C}$ for 93 "borderline" cultures of $S$. aureus examined in 1968. " Cultures with $\mathrm{MIC} \geqq 25 \mu \mathrm{g}$ methicillin per $\mathrm{ml}\left(48 \mathrm{hr}\right.$ at $\left.37^{\circ} \mathrm{C}\right)$.

J. MED. MICROBIOL.-VOL. 2 (1969) 
been considered sensitive by the criteria used in 1966 . Thus, 100 cultures fell into the original " borderline" category, and 93 of them were available for re-examination.

The disk tests at $37^{\circ} \mathrm{C}$ gave results similar to those shown in fig. 2, but at $30^{\circ} \mathrm{C}$ there was a very clear distinction between sensitive and resistant cultures (fig. 3). All 41 of the cultures that had a MIC of $25 \mu \mathrm{g}$ methicillin per $\mathrm{ml}$ or more grew right up to the $10-\mu \mathrm{g}$ disk at $30^{\circ} \mathrm{C}$, though with three of them there was a wide zone of thinning of growth around the disk. All 52 of the sensitive cultures gave clear zones of inhibition of at least $8 \mathrm{~mm}$ diameter. In the tube dilution tests at $30^{\circ} \mathrm{C}$ it was possible to separate the sensitive and resistant cultures after incubation for $18 \mathrm{hr}$ (fig. 4). There was an exact correspondence between the results obtained after $48 \mathrm{hr}$ at $37^{\circ} \mathrm{C}$ and after $18 \mathrm{hr}$ at $30^{\circ} \mathrm{C}$.

\section{TABLE}

Minimum inhibitory concentration (MIC) of methicillin and cloxacillin for 47 cultures of Staphylococcus aureus in tube dilution tests incubated at $37^{\circ}$ and $30^{\circ} \mathrm{C}$

\begin{tabular}{|c|c|c|c|c|c|c|c|c|c|c|c|c|c|}
\hline \multirow{2}{*}{ Antibiotic } & \multicolumn{2}{|c|}{ Incubation } & \multicolumn{11}{|c|}{ Number of cultures with MIC ( $\mu \mathrm{g}$ per ml) } \\
\hline & $\begin{array}{l}\text { temperature } \\
\left({ }^{\circ} \mathrm{C}\right)\end{array}$ & $\begin{array}{l}\text { time } \\
\text { (hr) }\end{array}$ & $0 \cdot 2$ & 0.4 & $0 \cdot 8$ & $1 \cdot 6$ & $3 \cdot 1$ & $6 \cdot 25$ & $12 \cdot 5$ & 25 & 50 & 100 & $>100$ \\
\hline Methicillin & $\begin{array}{l}37 \\
37 \\
30 \\
30 \\
30\end{array}$ & $\begin{array}{l}24 \\
48 \\
18 \\
24 \\
48\end{array}$ & $\begin{array}{l}0 \\
0 \\
0 \\
0 \\
0\end{array}$ & $\begin{array}{l}0 \\
0 \\
0 \\
0 \\
0\end{array}$ & $\begin{array}{l}0 \\
0 \\
0 \\
0 \\
0\end{array}$ & $\begin{array}{l}4 \\
0 \\
4 \\
2 \\
0\end{array}$ & $\begin{array}{r}10 \\
9 \\
15 \\
8 \\
1\end{array}$ & $\begin{array}{r}11 \\
12 \\
5 \\
14 \\
19\end{array}$ & $\begin{array}{r}10 \\
3 \\
0 \\
0 \\
4\end{array}$ & $\begin{array}{l}9 \\
0 \\
1 \\
0 \\
0\end{array}$ & $\begin{array}{l}3 \\
2 \\
5 \\
1 \\
0\end{array}$ & $\begin{array}{l}0 \\
2 \\
4 \\
1 \\
0\end{array}$ & $\begin{array}{r}0 \\
19 \\
13 \\
21 \\
23\end{array}$ \\
\hline Cloxacillin & $\begin{array}{l}37 \\
37 \\
30 \\
30 \\
30\end{array}$ & $\begin{array}{l}24 \\
48 \\
18 \\
24 \\
48\end{array}$ & $\begin{array}{l}8 \\
0 \\
0 \\
0 \\
0\end{array}$ & $\begin{array}{r}10 \\
9 \\
9 \\
3 \\
0\end{array}$ & $\begin{array}{r}15 \\
6 \\
16 \\
16 \\
17\end{array}$ & $\begin{array}{l}5 \\
6 \\
6 \\
6 \\
3\end{array}$ & $\begin{array}{l}3 \\
1 \\
6 \\
3 \\
3\end{array}$ & $\begin{array}{l}1 \\
2 \\
6 \\
7 \\
1\end{array}$ & $\begin{array}{l}1 \\
1 \\
2 \\
1 \\
0\end{array}$ & $\begin{array}{l}3 \\
1 \\
0 \\
7 \\
1\end{array}$ & $\begin{array}{l}0 \\
5 \\
0 \\
2 \\
1\end{array}$ & $\begin{array}{l}1 \\
5 \\
1 \\
0 \\
3\end{array}$ & $\begin{array}{r}0 \\
11 \\
1 \\
2 \\
18\end{array}$ \\
\hline
\end{tabular}

Routine tests for the detection of methicillin resistance

We examined the performance of a number of tests in current use in hospital laboratories for the detection of methicillin resistance, and included tests with cloxacillin because in Britain this is the most widely used of the penicillinaseresistant penicillins. A series of 47 epidemiologically distinct strains of $S$. aureus was tested; 23 of the cultures were unequivocally resistant to methicillin (MIC $\geqq 25 \mu \mathrm{g}$ methicillin per $\mathrm{ml}$ on incubation at $37^{\circ} \mathrm{C}$ for $48 \mathrm{hr}$ ) and 24 were sensitive. They were subjected to the following tests: (1) tube dilution sensitivity tests with methicillin and cloxacillin at $37^{\circ}$ and $30^{\circ} \mathrm{C}$; (2) disk diffusion tests with methicillin and cloxacillin on nutrient agar and salt agar at $37^{\circ} \mathrm{C}$ (Sutherland,1964; Churcher, 1968), and on nutrient agar at $30^{\circ} \mathrm{C}$; (3) growth from spot inocula on solid media containing methicillin or cloxacillin (salt agar at $37^{\circ} \mathrm{C}$, and nutrient agar at $30^{\circ} \mathrm{C}$ ).

Tube dilution sensitivity tests (table). The expected distinction in the MIC 

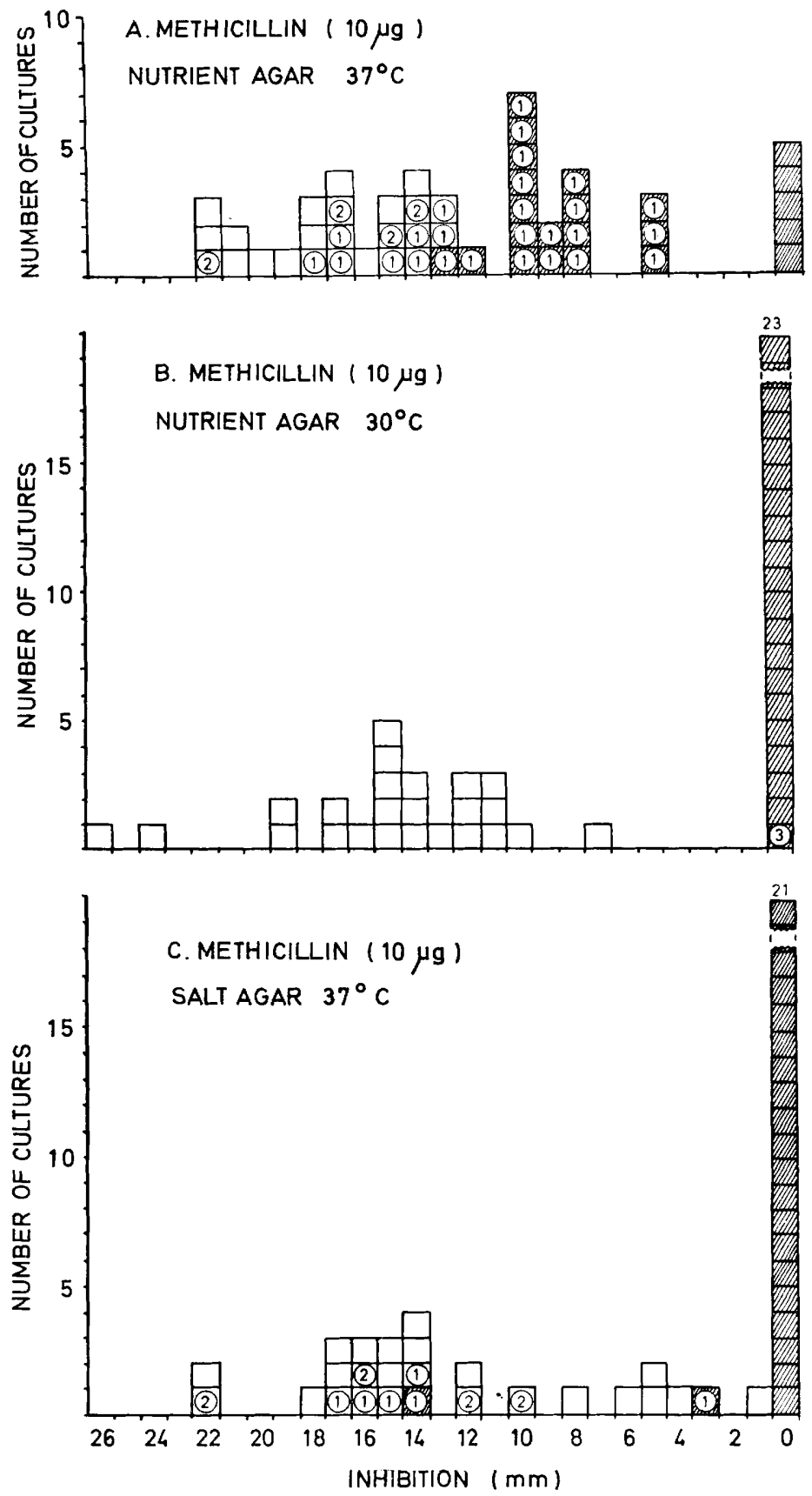

FIG. 5.--Size and character of zones of inhibition given by 23 methicillin-resistant and 24 methicillin sensitive cultures of $S$. aureus in methicillin $(10 \mu \mathrm{g})$ disk diffusion tests incubated on nutrient agar at $37^{\circ}$ and $30^{\circ} \mathrm{C}$, and on salt agar at $37^{\circ} \mathrm{C}$. $=$ Cultures with MIC $\geqq 25 \mu \mathrm{g}$ methicillin per ml $\left(48 \mathrm{hr}\right.$ at $\left.37^{\circ} \mathrm{C}\right)$. (1) = Colonies scattered within the zone; (2) = ring of colonies near periphery of zone of inhibition; (3) = growth up to disk, but zone of thinning. 
of methicillin between sensitive and resistant strains was observed at $37^{\circ} \mathrm{C}$ in $48 \mathrm{hr}$ and at $30^{\circ} \mathrm{C}$ in $18 \mathrm{hr}$. With cloxacillin, however, it was apparent only at $30^{\circ} \mathrm{C}$ and after $48 \mathrm{hr}$.

Disk diffusion tests on nutrient agar (figs. 5 and 6 ). At $37^{\circ} \mathrm{C}$ tests with cloxacillin disks $(5 \mu \mathrm{g})$ were very much less satisfactory than with methicillin disks $(10 \mu \mathrm{g})$, and only 2 out of the 23 resistant strains showed a significant reduction in zone size. Repetition of the tests with $2 \mu \mathrm{g}$ cloxacillin disks gave little improvement. At $30^{\circ} \mathrm{C}$ the methicillin disk test gave clear-cut results. The cloxacillin disk test was somewhat more satisfactory at $30^{\circ} \mathrm{C}$ than at $37^{\circ} \mathrm{C}$, and it was possible to recognise 17 of the 23 resistant strains if very thin growth up to the disk was taken into account.

Disk diffusion tests on salt agar at $37^{\circ} \mathrm{C}$ (figs. 5 and 6 ). With a $10 \mu \mathrm{g}$ methicillin disk, 21 of the 23 resistant strains grew right up to the disk. The two other strains showed zones of inhibition, in one case wide, but in both cases containing numerous colonies amounting almost to confluent growth. A number of the sensitive cultures gave narrow but clear-cut zones, and the remaining sensitive cultures gave wider zones, some of which contained a small number of colonies. In tests with cloxacillin disks $(5 \mu \mathrm{g})$, nearly half the resistant strains gave zones of inhibition containing numerous discrete colonies and the sensitive strains all gave relatively large clear zones.

Growth on agar containing antibiotics. All but one of the resistant strains gave confluent growth on salt agar containing $10 \mu \mathrm{g}$ methicillin per $\mathrm{ml}$ or $2 \mu \mathrm{g}$ cloxacillin per $\mathrm{ml}$ after overnight incubation at $37^{\circ} \mathrm{C}$, but a few of the sensitive strains also grew on cloxacillin salt agar, one of them heavily. Sensitive and resistant strains were sharply distinguished by their ability to grow overnight on nutrient agar containing $10 \mu \mathrm{g}$ methicillin per $\mathrm{ml}$ at $30^{\circ} \mathrm{C}$.

\section{Discussion}

In 1960, when we began our survey of the sensitivity of Staphylococcus aureus to methicillin, naturally-occurring resistant strains had not been seen. It is therefore fortunate that the screening test we chose as a matter of convenience proved to be a sensitive method for the detection of resistance. Until 1966 , however, we used excessively severe confirmatory tests, and this resulted in the final classification as sensitive of some $20-25$ per cent. of the resistant cultures. In three separate investigations between 1964 and 1968 there was little difference in the proportion of methicillin-resistant cultures with " borderline" characters, that is to say, with a slower than average growth rate at $37^{\circ} \mathrm{C}$ in the presence of methicillin. A retrospective correction of the frequency of resistance observed in the earlier years of the survey can therefore be made with some confidence.

Methicillin resistance in $S$. aureus has increased considerably in frequency in Britain since it was first observed in the autumn of 1960 . At that time Jevons (1961) found only 3 out of 5540 cultures ( 0.06 per cent.) to be resistant, but in 1968 we found 278 methicillin-resistant staphylococci in a comparable series of 10,575 cultures ( 2.63 per cent.). More striking increases have been observed in parts of continental Europe; in Denmark, for example, by 1966 
A. CLOXACILLIN $(5 \mu \mathrm{g})$
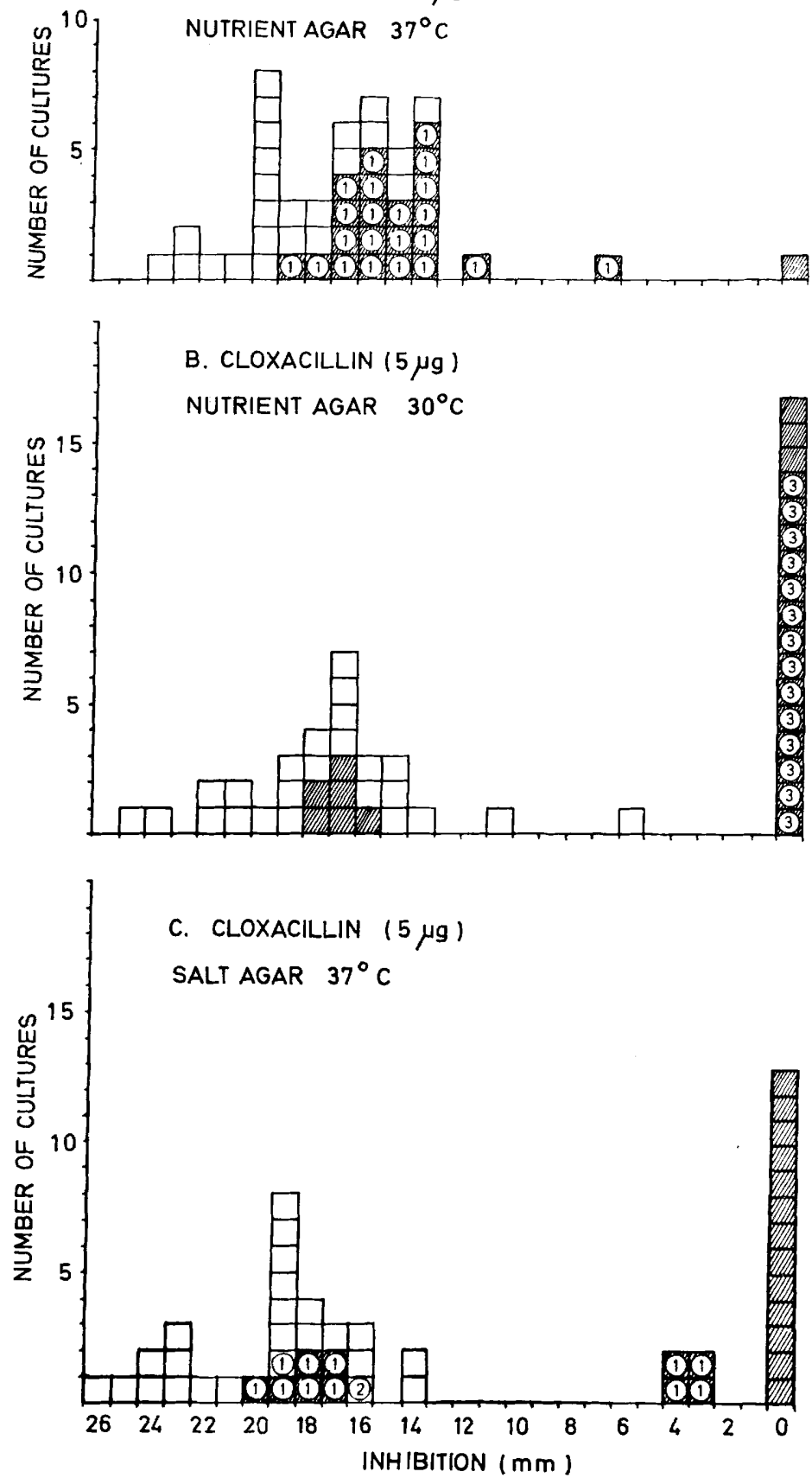

FIG. 6.- Size and character of zones of inhibition given by 23 methicillin-resistant and 24 methicillinsensitive cultures of $S$. aureus in cloxacillin $(5 \mu \mathrm{g})$ disk diffusion tests incubated on nutrient agar at $37^{\circ}$ and $30^{\circ} \mathrm{C}$ and on salt agar at $37^{\circ} \mathrm{C}$. Cultures with MIC $\geqq 25 \mu \mathrm{g}$ methicillin per $\mathrm{ml}\left(48 \mathrm{hr}\right.$ at $\left.37^{\circ} \mathrm{C}\right) .(1)=$ Colonies scattered within the zone; (2) = ring of colonies near periphery of zone of inhibition; (3) = growth up to disk, but zone of thinning. 
some 10 per cent. of all $S$. aureus cultures isolated from cases of bacteriaemia were resistant to methicillin (Eriksen et al., 1967).

Some methicillin-resistant strains appear to grow rather more slowly than others in the presence of methicillin at $37^{\circ} \mathrm{C}$. Whether this character corresponds to a low "basal resistance "--defined by Benner and Kayser (1968) in terms of the proportion of a culture able to form colonies at $37^{\circ} \mathrm{C}$ on a solid medium containing methicillin-remains to be seen, but on the present evidence it must be assumed that all strains of $S$. aureus with " heterogeneous resistance " to methicillin would be difficult to eradicate from the bloodstream of bacteriaemic patients with penicillinase-resistant penicillins or cephalosporins (Chabbert et al., 1965; Bastin, Worms and Acar, 1967). Our tests should therefore be designed to detect every staphylococcus with this resistance.

We are continuing to use the disk diffusion test with a $10 \mu \mathrm{g}$ methicillin disk on a plate of phage-typing agar incubated at $30^{\circ} \mathrm{C}$ as a screening test, and are satisfied that practically all resistant strains will grow up to the disk or to within $1 \mathrm{~mm}$ of it. Confirmation of resistance is made by determining the MIC at $37^{\circ} \mathrm{C}$ after 48 hours' incubation, but we believe that it could be done equally well by carrying out a second disk test at $30^{\circ} \mathrm{C}$ after purification of the strain by subculture from a single colony. Some form of confirmatory test does seem to be necessary, because under our conditions of routine testing, we appear to be falsely recording resistance in about 1 out of every 100 sensitive cultures. The most likely explanation is that rather less than 1 per cent. of our methicillin disks have a slightly reduced potency. The distribution of "false-positive" reactions suggested that the defective disks were randomly distributed among the different batches of disks. It is obvious that, when a relatively uncommon resistance is being sought, a very high degree of uniformity of disk potency is necessary. Investigation of cultures giving such false-positive reactions showed that, although they were nearly always easily recognisable as sensitive on a second disk test at $30^{\circ} \mathrm{C}$, they were frequently examples of a multiple-antibiotic resistant strain of $S$. aureus that formed a large amount of penicillinase and gave a somewhat narrowed zone of inhibition. Another possible cause of falsepositive results is the presence in a culture of a minority population of methicillin-resistant coagulase-negative staphylococci that is eliminated in the course of purification before the confirmatory test is carried out.

Tests for resistance to methicillin in the hospital laboratory are somewhat inconvenient, because there is no reliable way of including them in a battery of tests with other antibiotics on a single plate. Methicillin-sensitivity testing must therefore be a separate operation, and there are several suitable methods. If a $30^{\circ} \mathrm{C}$ incubator is available, a disk test with methicillin $(10 \mu \mathrm{g}$ per disk) made at this temperature is probably the method of choice. It can be made on segments of a nutrient agar or blood agar plate spread evenly either with undiluted broth culture or with growth from a plate or slope culture. Medium may be saved by the use of a spot inoculation test on a nutrient agar plate containing $10 \mu \mathrm{g}$ methicillin per $\mathrm{ml}$ incubated overnight at $30^{\circ} \mathrm{C}$. In our experience, such plates can be stored at $4^{\circ} \mathrm{C}$ for up to 5 days without significant loss of potency of the antibiotic. 
If the tests must be performed at $37^{\circ} \mathrm{C}$, the best available method is to use a $10 \mu \mathrm{g}$ methicillin disk on salt agar (Churcher, 1968), but there may be occasional difficulties in interpreting the results. The development of growth right up to the edge of the disk indicates resistance, but some sensitive cultures give very narrow zones. Resistance should also be suspected, whatever the zone size, when a zone of inhibition contains large numbers of evenly distributed colonies, and further tests, e.g., a tube dilution MIC test incubated for $48 \mathrm{hr}$ at $37^{\circ} \mathrm{C}$, may have to be performed.

Although all methicillin-resistant $S$. aureus cultures show cross-resistance to cloxacillin when tested by appropriate methods, most of the routine testing methods with cloxacillin give unsatisfactory results. Disk tests on nutrient agar at $37^{\circ} \mathrm{C}$ are virtually useless and disk tests on nutrient agar at $30^{\circ} \mathrm{C}$ or on salt agar at $37^{\circ} \mathrm{C}$ fail to detect nearly one-quarter of the resistant cultures. A spot inoculation test on cloxacillin salt agar gives relatively reliable results, but an occasional sensitive culture may appear to be resistant.

\section{SUMMARY}

Some methicillin-resistant cultures of Staphylococcus aureus give equivocal results when tested in disk diffusion tests or tube dilution MIC tests incubated at $37^{\circ} \mathrm{C}$.

Practically all resistant cultures have the following characters: (1) they give growth up to or to within $1 \mathrm{~mm}$ of a $10 \mu \mathrm{g}$ methicillin disk in a disk diffusion test on nutrient agar or blood agar incubated at $30^{\circ} \mathrm{C}$, and (2) they show a MIC of $25 \mu \mathrm{g}$ methicillin per ml or greater after incubation for $18 \mathrm{hr}$ at $30^{\circ} \mathrm{C}$, or for $48 \mathrm{hr}$ at $37^{\circ} \mathrm{C}$, in a tube dilution test in nutrient broth.

Tests for growth at $37^{\circ} \mathrm{C}$ on methicillin salt agar, or on salt agar with a methicillin disk, are also generally reliable, but some batches of methicillin salt agar are relatively inhibitory for resistant staphylococci.

Routine sensitivity tests with cloxacillin give unsatisfactory results.

We wish to thank Mr Frank Lach-Szyrma and Mrs D. P. Martin for excellent technical assistance, and to acknowledge a generous gift of cloxacillin from the Beecham Research Laboratories.

\section{REFERENCES}

ANNEAR, D. I.

BARBER, MARY

BAstin, R., WORMS, R., AND ACAR, J. F.

BENNER, E. J., AND KAYSER, F. H.

Blair, J. E., AND Williams, R. E. O.

ChabBert, Y-A., AND Baudens, J-G.

Chabbert, Y-A., Baudens, J-G., Acar,

J. F., AND Gerbaud, G. R.

ChURChER, Gillian M.

DYKE, $K$, G $H$.

Dyke, K. G. H., Jevons, M. Patricia, AND PARKER, M. T.

ERIKSEN, K. R., BÜLow, P., Rosendal, K., FABER, V., AND JesSEn, $O$.
1968. Med. J. Austral., 1, 444.

1964. J. Gen. Microbiol., 35, 183.

1967. Path. Biol., Paris, 15, 1205.

1968. Lancet, 2, 741.

1961. Bull. Wld Hlth Org., 24, 771.

1962. Annls Inst. Pasteur, Paris, 103, 222.

1965. Revue fr. Etud. clin. biol., 10, 495.

1968. J. Clin. Path., 21, 213.

1969. J. Med. Microbiol., 2, 261.

1966. Lancet, 1, 835.

1967. Acta path. microbiol. scand., Suppl. 187, p. 24. 
Jevons, M. Patricia - . . . . . 1961. Br. Med. J., 1, 124.

Jevons, M. Patricia, Coe, A. W., AND 1963. Lancet, 1, 904.

PARKer, M. T.

KNox, R. . . . . . . . . . 1961. Br. Med. J., 1, 126.

Parker, M. T., And Jevons, M. Patricia 1964. Post-grad. Med. J., 40, Suppl., p. 170.

Rolinson, G. N. . . . . . . . . 1961. Br. Med. J., 1, 125.

Sutherland, R. . . . . . . . . 1964. Post-grad. Med. J., 40, Suppl., p. 187.

Sutherland, R., and Rolinson, G. N.. 1964. J. Bact., 87, 887. 